\title{
Assembly of Proteins to Postsynaptic Densities after Transient Cerebral Ischemia
}

\author{
Bing-Ren Hu, ${ }^{1}$ Minkyu Park, ${ }^{2}$ Maryann E. Martone, ${ }^{1}$ Wolfgang H. Fischer, ${ }^{2}$ Mark H. Ellisman, ${ }^{1}$ and \\ Justin A. Zivin 1 \\ ${ }^{1}$ Department of Neuroscience, National Center for Microscopy and Imaging Research at San Diego, and Veterans Affairs \\ Medical Center at San Diego, University of California, San Diego, La Jolla, California 92093-0624, and 2The Clayton \\ Foundation Laboratories for Peptide Biology, The Salk Institute, La Jolla, California 92037
}

Transient ischemia leads to changes in synaptic efficacy and results in selective neuronal damage during the postischemic phase, although the mechanisms are not fully understood. The protein composition and ultrastructure of postsynaptic densities (PSDs) were studied by using a rat transient ischemic model. We found that a brief ischemic episode induced a marked accumulation in PSDs of the protein assembly ATPases, $N$-ethylmaleimide-sensitive fusion protein, and heatshock cognate protein-70 as well as the BDNF receptor (trkB) and protein kinases, as determined by protein microsequencing. The changes in PSD composition were accompanied by a 2.5-fold increase in the yield of PSD protein relative to controls. Biochemical modification of PSDs correlated well with an increase in PSD thickness observed in vivo by electron microscopy. We conclude that a brief ischemic episode modifies the molecular composition and ultrastructure of synapses by assembly of proteins to the postsynaptic density, which may underlie observed changes in synaptic function and selective neuronal damage.

Key words: postsynaptic density; synaptic plasticity; protein kinases; microsequencing; cerebral ischemia; electron microscope; neuronal damage
A brief cerebral ischemic episode causes alterations of synaptic function and selective neuronal death in the postischemic phase. Generally, a mild ischemic episode potentiates synaptic transmission (Andiné et al., 1992; Miyazaki et al., 1993, 1994; Hammond et al., 1994; Gao and Xu, 1996), whereas more severe ischemia suppresses neurotransmission (Furukawa et al., 1990; Xu, 1995; Dalkara et al., 1996) and leads to cell death in selected neuronal populations. This occurs in a delayed manner, i.e., neuronal death occurs $\sim 3$ d after an ischemic episode (Kirino et al., 1982; Pulsinelli et al., 1982; Smith et al., 1984). The molecular mechanisms underlying the postischemic changes of synaptic function and neuronal damage are not fully understood. Electron microscopic studies have demonstrated that increases of membranous organelles, deposition of dark substances, and transient disaggregation of polyribosomes are present in some postischemic neurons (Krino and Sano, 1984a,b; Petito and Pulsinelli, 1984; Rafols et al., 1995). Transient cerebral ischemia induces increases in extracellular glutamate and intracellular calcium (Choi, 1995; Rothman and Olney, 1995), induction of gene expression (Nowak et al., 1990; Kiessling et al., 1993; Neumann-Haefelin et al., 1994), production of free radicals (Chan, 1996), alteration of protein kinases (Cardell et al., 1990; Wieloch et al., 1991; Aronowski et al., 1992; Hu and Wieloch, 1995; Hu et al., 1995), and inhibition of protein synthesis (Hossmann, 1993; Hu and Wieloch, 1993).

To explore possible molecular mechanisms underlying postischemic alterations of synaptic function and selective neuronal damage, we have examined the composition and ultrastructure of

Received Aug. 12, 1997; revised Oct. 13, 1997; accepted Oct. 31, 1997.

This work was supported by National Institutes of Health Grants NS36810-01 to B.R.H., NS28121 to J.A.Z., RR04050 to M.H.E., and S10 RR 11404-01A1 to W.H.F.

Correspondence should be addressed to Dr. Bing-Ren Hu, Department of Neurosciences, School of Medicine, University of California, San Diego, 9500 Gilman Drive, La Jolla, CA 92093-0624.

Copyright (C) 1998 Society for Neuroscience $0270-6474 / 98 / 180625-09 \$ 05.00 / 0$ postsynaptic densities (PSDs) in the postischemic brain by using a transient cerebral ischemia model. The PSD is a specialized cytoskeletal structure lying beneath the postsynaptic membrane (Harris and Kater, 1994; Kennedy, 1994). The fact that neurotransmitter receptors, ion channels, and signaling molecules are highly enriched in PSDs, as compared with parasynaptic membranes, suggests an important function for PSDs in the anchoring and targeting of functional proteins required for receiving and transducing synaptic signals in postsynaptic neurons.

In this study we present evidence that a brief ischemic episode induces a marked increase of the protein assembly ATPases, $N$-ethylmaleimide-sensitive fusion protein (NSF), and heatshock cognate protein-70 (HSC70) as well as trkB within PSDs. The changes of protein composition are accompanied by an increase of PSD protein yield and changes in the ultrastructure of PSDs. In addition, the ischemic episode also causes a marked translocation of two signaling molecules, CaM-kinase II and protein kinase $\mathrm{C}$, to PSDs. These synaptic changes may underlie the alterations in synaptic transmission and postischemic neuronal damage observed after transient ischemia.

\section{MATERIALS AND METHODS}

Materials. Leupeptin, pepstain, aprotinin, sodium orthovanadate, phosphotungstic acid (PTA), and dithiothreitol (DTT) were purchased from Sigma (Sigma, St. Louis, MO). The antibodies against calcium/ calmodulin-dependent-kinase II and synaptophysin were purchased from Boehringer Mannheim (Boehringer Mannheim/Biochemica, Mannheim, Germany) and antibodies to the NMDA receptor subunit-1 and -2 from Chemicon (Temecula, CA); antibodies to heat-shock cognate protein 70 (HSC70) and syntaxin were purchased from StressGen (Victoria, British Columbia); antibodies to NSF and p97 were generous gifts from Drs. Mitsuo Tagaya (School of Life Sciences, Tokyo University of Pharmacy and Life Sciences, Japan) and Vivek Malhotra (Department of Biology, University of California, San Diego), respectively; the antibody to protein kinase C- $\beta$ was a gift from Dr. Tsunao Saitoh (Department of Neuroscience, University of California, San Diego); the antibody to 
PSD-95 was purchased from Affinity BioReagents (Neshanic Station, $\mathrm{NJ}$ ), and peroxidase-linked secondary antibodies were purchased from Amersham (Arlington Heights, IL).

Ischemia model. Male Wistar rats (250-300 gm) were fasted overnight. All experimental procedures were approved by the subcommittee on animal studies of the Veterans Affairs Medical Center, San Diego. Anesthesia was induced with $3 \%$ halothane, followed by maintenance with $1-2 \%$ halothane in an oxygen/nitrous oxide (30/70\%) gas mixture. Catheters were inserted into the external jugular vein, tail artery, and tail vein to allow for blood sampling, arterial blood pressure recording, and drug infusion. Both common carotid arteries were encircled by loose ligatures. At $15 \mathrm{~min}$ before ischemia induction and $15 \mathrm{~min}$ postischemia, blood gases were measured and adjusted to $\mathrm{PaO}_{2}>90 \mathrm{mmHg}, \mathrm{PaCO}_{2}$ $35-45 \mathrm{mmHg}, \mathrm{pH} 7.35-7.45$, by adjusting the tide volume of the respirator. Bipolar EEG was recorded every 5-10 min before ischemia, continuously during the ischemic insult, and every $5 \mathrm{~min}$ after ischemia until the rat recovered from the anesthesia. At the beginning of a $30 \mathrm{~min}$ steady-state period before the induction of ischemia, the inspired halothane concentration was decreased to $0.5 \%$, and $150 \mathrm{IU} / \mathrm{kg}$ heparin was administered intravenously. Blood was withdrawn via the jugular catheter to produce a mean arterial blood pressure of $50 \mathrm{mmHg}$, and both carotid arteries were clamped. Blood pressure was maintained at 50 $\mathrm{mmHg}$ during the ischemic period by withdrawing or infusing blood through the jugular catheter. At the end of the ischemic period the clamps were removed and the blood reinfused through the jugular catheter, followed by $0.5 \mathrm{ml}$ of $0.6 \mathrm{M}$ sodium bicarbonate. In all experiments, brain temperature was maintained at $37^{\circ} \mathrm{C}$ before, during, and after ischemia (15 min of reperfusion). Halothane was discontinued at the end of ischemia and all wounds were sutured. At $4 \mathrm{hr}$ of reperfusion, the animals were reanesthetized, tracheotomized, and artificially ventilated. Tissue samples for the biochemical study were obtained by freezing the brain in situ with liquid nitrogen. The neocortex was dissected at $-15^{\circ} \mathrm{C}$. For electron microscopic studies the brains were perfused with ice-cold $2 \%$ paraformaldehyde and $2.5 \%$ glutaraldehyde in $0.1 \mathrm{M}$ cacodylate buffer. Sham-operated rats were subjected to the same surgical procedures but without the clamping of arteries. Each experimental group consisted of at least three rats.

Preparation of subcellular fractions and quantification of postsynaptic densities. Isolation of PSDs was performed according to the procedure of Carlin et al. (1980), except that $3 \mathrm{gm}$ of brain tissue was used for each preparation, and sodium orthovanadate $(0.1 \mathrm{~mm})$ and protease inhibitors $(10 \mu \mathrm{g} / \mathrm{ml}$ leupeptin, $5 \mu \mathrm{g} / \mathrm{ml}$ pepstain, $5 \mu \mathrm{g} / \mathrm{ml}$ aprotinin, and $0.2 \mathrm{~mm}$ phenylmethylsulfonyl fluoride) were included in all buffers. Briefly, neocortex samples were obtained from 16 rats per condition. Within each condition, four samples were prepared by pooling neocortical tissue from four rats $(\sim 3 \mathrm{gm})$ for purification of PSDs. Samples were homogenized and then subjected to several steps of differential centrif ugation to obtain crude synaptosomal fractions. This fraction was separated by $0.85 / 1.0 / 1.2$ $\mathrm{M}$ sucrose density gradient centrifugation. The synaptosomes were obtained from the 1.0/1.2 $\mathrm{M}$ sucrose interface, and light plasma membranes (LMs) were collected from the $0.85 / 1.0 \mathrm{M}$ sucrose interface. After being washed with $0.5 \%$ Triton $\mathrm{X}-100$, synaptosomal pellets were collected by centrifugation and then subjected to a second 1.0/1.5/2.0 M sucrose density gradient centrifugation. The PSDs were obtained from the 1.5/2.0 $\mathrm{M}$ interface of the sucrose gradients. The PSD fraction was diluted with an equal volume of $1 \%$ Triton X-100/300 mM KCl solution, mixed for 5 min, and centrifuged at $275,000 \times g$ for $1 \mathrm{hr}$. The PSDs were washed again with $0.5 \%$ Triton $\mathrm{X}-100 / 150 \mathrm{~mm} \mathrm{KCl}$ and suspended in a buffer containing (in mM) 50 Tris/ $\mathrm{HCl}, \mathrm{pH} 7.4,0.5 \mathrm{DTT}, 100 \mathrm{KCl}, 0.2$ phenylmethylsulfonyl fluoride, and 0.2 orthovanadate with $10 \mu \mathrm{g} / \mathrm{ml}$ leupeptin, $5 \mu \mathrm{g} / \mathrm{ml}$ pepstain, and $5 \mu \mathrm{g} / \mathrm{ml}$ aprotinin. A portion of the PSDs was dissolved in $0.3 \%$ SDS for protein concentration measurement. The yield of the PSD preparation was calculated and expressed as milligram of PSD protein per gram of neocortex. The cytosolic fraction (S3) was prepared as described previously (Hu and Wieloch, 1994). The nuclear fraction (N) was isolated by the method of Thompson (1973). Protein concentration was determined by the micro-bicinchoninic acid (BCA) method of Pierer (Pierce, Rockford, IL).

Protein sequencing. PSDs were prepared from 25 postischemic rat brains and the same number of controls. Internal peptide microsequencing of the ischemia-induced PSD proteins was conducted according to the protocol of Fischer et al. (1991). Briefly, the PSD proteins were separated by $8 \%$ SDS-polyacrylamide gel electrophoresis (SDS-PAGE) and blotted to polyvinylidene difluoride (PVDF) membrane. The protein bands on the membranes were stained in a solution of $0.1 \%$ Amido
Black 10B (Bio-Rad, Richmond, CA) in 45\% methanol/10\% acetic acid in water and then rinsed in water. The ischemia-induced protein bands $(105,79,73,61,59$, and 51 molecular sizes in $\mathrm{kDa}$; see Fig. 4) then were cut out. Each protein band was combined with its counterpart from four or five gels, transferred to a $1.5 \mathrm{ml}$ tube, preincubated with $0.5 \%$ polyvinylpyrrolidone-40 (PVP-40) dissolved in $100 \mathrm{~mm}$ trifluoroacetic acid, and then extensively washed in water. Trypsin $(1 \mu \mathrm{g})$ dissolved in 30 $\mu \mathrm{l}$ of $100 \mathrm{~mm}$ TES ( $N$-tris[hydroxymethyl]methyl-2-aminoethanesulfonic acid) buffer, $\mathrm{pH} 8.0$, was added into the tube, and the digestion was allowed to proceed overnight at $37^{\circ} \mathrm{C}$. The digested peptides were resolved by a $\mathrm{C} 18$ reverse-phase HPLC. The peptide fractions were analyzed by Edman degradation, using automated protein sequencers (470A or 494, Applied Biosystems, Foster City, CA). Sequences obtained were compared with protein sequences in the GenBank data base, using the Blast network service via the National Center for Biotechnology Information.

Electron microscopic studies. Electron microscopic studies were performed with brain tissue sections from three rats and with isolated PSDs from three different preparations (each preparation consisted of samples pooled from four rat brains) in each experimental group. Tissue sections from experimental and control animals were stained with $1 \%$ ethanolic phosphotungstic acid (E-PTA) by the method of Bloom and Aghajanian $(1966,1968)$. Coronal brain sections were cut to a thickness of $200 \mu \mathrm{m}$ with a Vibratome through the level of the dorsal hippocampus and post-fixed for $1 \mathrm{hr}$ with $4 \%$ glutaraldehyde in $0.1 \mathrm{~m}$ cacodylate buffer, $\mathrm{pH}$ 7.4. Sections then were dehydrated in an ascending series of ethanol to $100 \%$ and stained for $1 \mathrm{hr}$ with $1 \%$ phosphotungstic acid prepared by dissolving $0.1 \mathrm{gm}$ of PTA in $10 \mathrm{ml}$ of 100 ethanol and then adding four drops of $95 \%$ ethanol from a Pasteur pipette. Sections were embedded in Durcopan ACM. Isolated PSDs were fixed with $4 \%$ glutaraldehyde in 0.1 $\mathrm{M}$ cacodylate buffer, $\mathrm{pH} 7.4$, osmicated for $60 \mathrm{~min}$ in $1 \%$ osmium tetroxide, stained en bloc in $1 \%$ aqueous uranyl acetate, dehydrated, and embedded in Durcopan ACM. Ultrathin and semithin $(1 \mu \mathrm{m})$ sections of parietal cortex (layers I-IV) were cut and evaluated with a JEOL 100CX electron microscope or a JEOL 4000EX intermediate high-voltage electron microscope without additional staining. Sections of isolated PSDs were counterstained with lead citrate before examination in the electron microscope.

For analysis of synaptic density, random micrographs were obtained at a magnification of $8300 \times$ from E-PTA-stained sections of paramedian cortex from control and postischemic brains. An equal number of micrographs was obtained from each of three animals in each group. Negatives were digitized into a MacIntosh computer at a resolution of $600 \mathrm{dpi}$, and images were viewed with Adobe Photoshop. Statistical analysis was performed with the Student's $t$ test.

Immunoblot. Equal amounts of the PSD fraction (PSDs; $5 \mu \mathrm{g}$ ), light membrane fraction (LMs; $40 \mu \mathrm{g}$ ), cytosolic fraction (S3; $100 \mu \mathrm{g})$, or nuclear fraction $(\mathrm{N} ; 40 \mu \mathrm{g})$ were applied onto $8 \%$ SDS-PAGE and analyzed by an immunoblotting technique (Hu and Wieloch, 1994). Antibodies against NMDA receptor subunit 1 (NR1) and subunit 2 (NR2) $(0.2 \mu \mathrm{g} / \mathrm{ml}$ of each antibody), TrkB (1:1000), 5-HT receptor $2 \mathrm{~A}$ $(0.5 \mu \mathrm{g} / \mathrm{ml}), \mathrm{CaM}$-kinase II $(0.2 \mu \mathrm{g} / \mathrm{ml}), \beta$-subtype of protein kinase C (1:1000), NSF (1:4000), HSC-70 (1:1500), p97 (1:2000), PSD-95 (1:3000), synaptophysin $(1: 3000)$, syntaxin $(1: 1500)$, or $\beta$-tubulin $(1: 2000)$ were used as primary antibodies; horseradish peroxidase-labeled anti-rabbit (1:2000) or anti-mouse antibodies (1:3000) were used as secondary antibodies. Immunoblots were developed with an ECL system (Amersham).

\section{RESULTS}

\section{Increase of yield and structural modification of the PSDs}

To study the protein composition of PSDs, we purified PSD structures from four different preparations from 16 shamoperated control rats and 16 rats subjected to $15 \mathrm{~min}$ of transient cerebral ischemia, followed by $4 \mathrm{hr}$ of reperfusion (referred to as the postischemic condition). Unexpectedly, we found that the yield of postischemic PSDs increased by a factor of $2.49 \pm 0.23$ relative to sham-operated controls (Fig. 1). The yield of PSDs was $111.68 \mu \mathrm{g}$ per gram tissue in control brains and $278.06 \mu \mathrm{g}$ per gram tissue in postischemic brains. There were no significant differences in the yield of LMs (Fig. 1) or other subcellular fractions between the two groups (data not shown). 


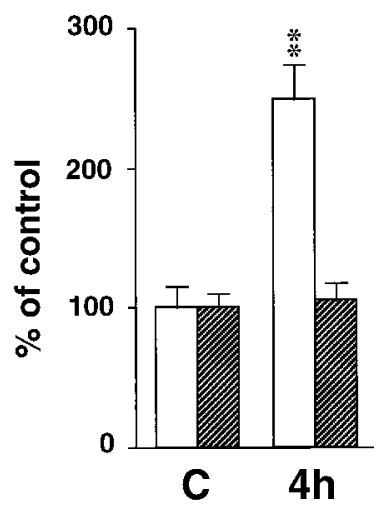

Figure 1. Yield of postsynaptic densities (PSDs; open bars) and light plasma membranes (LMs; hatched bars) from sham-operated rats $(C)$ and rats subjected to $15 \mathrm{~min}$ of ischemia, followed by $4 \mathrm{hr}$ of reperfusion (4h). Data were were expressed as mean \pm SD percentage of control. A significant difference in protein yield $(* *)$ was observed between the two groups ( $p<0.01$, Student's $t$ test).

To explore a possible structural basis for the increased yield of PSDs after a brief ischemic episode, we analyzed the ultrastructure of the isolated PSDs by transmission electron microscopy. Figure 2 illustrates the fine structure of the isolated PSDs. We found a major difference in the appearance of isolated PSDs between postischemic and control groups. In the sham-operated controls isolated PSDs were thin and often curved (Fig. $2 A$ ). In comparison, the postischemic PSDs were thicker and straighter (Fig. 2B), suggesting that they suffered less deformation during isolation than did the thinner control PSDs. Examination of isolated PSDs from the control brains revealed two populations of PSD-like structures. One consisted of trilaminar structures without an obvious PSD thickening (Fig. 2A, arrowheads). The other population consisted of classical PSD structures previously described in several studies (Fig. 2A, arrow) (Cohen et al., 1977; Carlin et al., 1980; Suzuki et al., 1993). The trilaminar structures were rarely seen in the PSD preparations from reperfused brains (Fig. 2B).

To follow up on these results, we examined the morphology and number of PSDs in tissue sections from rat cortex stained with E-PTA. The E-PTA method selectively stains the postsynaptic density, the presynaptic grid, and material in the synaptic cleft but leaves most other structures less stained (Bloom and Aghajanian, 1966, 1968). No significant differences were observed in the presynaptic grids and cleft material between control and postischemic synapses in the E-PTA-stained sections. However, clear differences were seen in PSD ultrastructure between the two groups. The PSDs of controls were thin and condensed (Fig. 3A). In contrast, most of the PSDs from postischemic animals were thicker with more flocculent material attached to the PSD, spreading out from the postsynaptic side. Also, most of the control PSDs exhibited greater electron density than those from postischemic cortex (Fig. 3B). These differences were highly consistent in all regions of neocortex examined.

To clarify whether the increase of PSD protein yield from postischemic brains was attributable to an increase in the number of synapses, we computed synaptic densities in E-PTA sections. We counted 1583 cortical synapses in 48 micrographs from controls and 1745 synapses in 61 micrographs from postischemic brains from a total of four rats in each group. Synaptic density was $40.81 \pm 13.13($ mean $\pm \mathrm{SD})$ per $100 \mu \mathrm{m}^{2}$ in controls and $37.27 \pm$ 9.39 (mean $\pm \mathrm{SD}$ ) per $100 \mu \mathrm{m}^{2}$ in postischemic brains. This

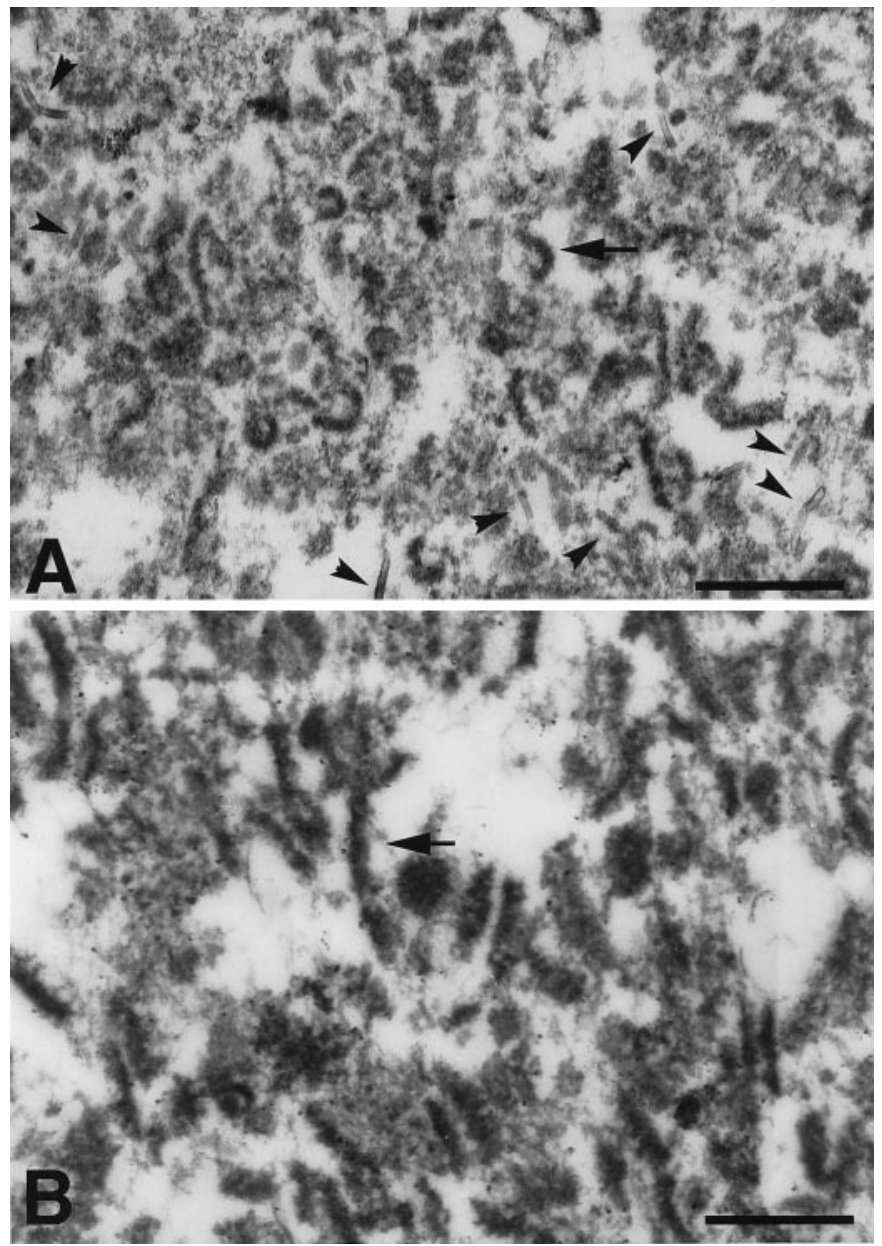

Figure 2. Electron micrographs of isolated cortical PSDs from shamoperated rats $(A)$ and rats subjected to $15 \mathrm{~min}$ of ischemia, followed by 4 $\mathrm{hr}$ of reperfusion $(B)$. Three preparations of isolated PSDs were used for electron microscopic study. Arrows indicate isolated PSDs in both control and $4 \mathrm{hr}$ reperfusion. Arrowheads point to examples of trilaminar structures observed only in control PSDs, but not in $4 \mathrm{hr}$ reperfused PSDs. Scale bars in $A$ and $B, 0.5 \mu \mathrm{m}$.

difference was not statistically significant (Fig. 4). These values are comparable with reports of 39 synapses $/ 100 \mu \mathrm{m}^{2}$ (Lee et al., 1980) and 44/100 $\mu \mathrm{m}^{2}$ (Harris et al., 1992) reported for heavy metal-stained sections of the adult rat hippocampus.

\section{Changes of PSD protein composition}

To study the biochemical basis of the structural modification of the PSDs further, we analyzed the protein composition of the PSDs, using SDS-PAGE in conjunction with an internal peptide microsequencing technique (Fischer et al., 1991). Equal amounts of PSD protein from the postischemic and control brains were analyzed in parallel to compare protein contents by SDS-PAGE. As shown in Figure $5 B$, the protein profile of the control PSDs stained with Coomassie blue revealed a typical PSD pattern, as described by Cohen et al. (1977) and Carlin et al. (1980). In comparison with controls, there were marked increases in six protein bands $(79,73,59,51,23$, and $18 \mathrm{kDa})$ and decreases in two protein bands (105 and $63 \mathrm{kDa})$ in the postischemic PSDs (Fig. $5 B$ ). These changes were consistent in four PSD preparations (each preparation consisted of pooled samples from 16 rats). The identities of these proteins were analyzed by internal peptide microsequencing (Table 1). We found that the $79 \mathrm{kDa}$ band is the 

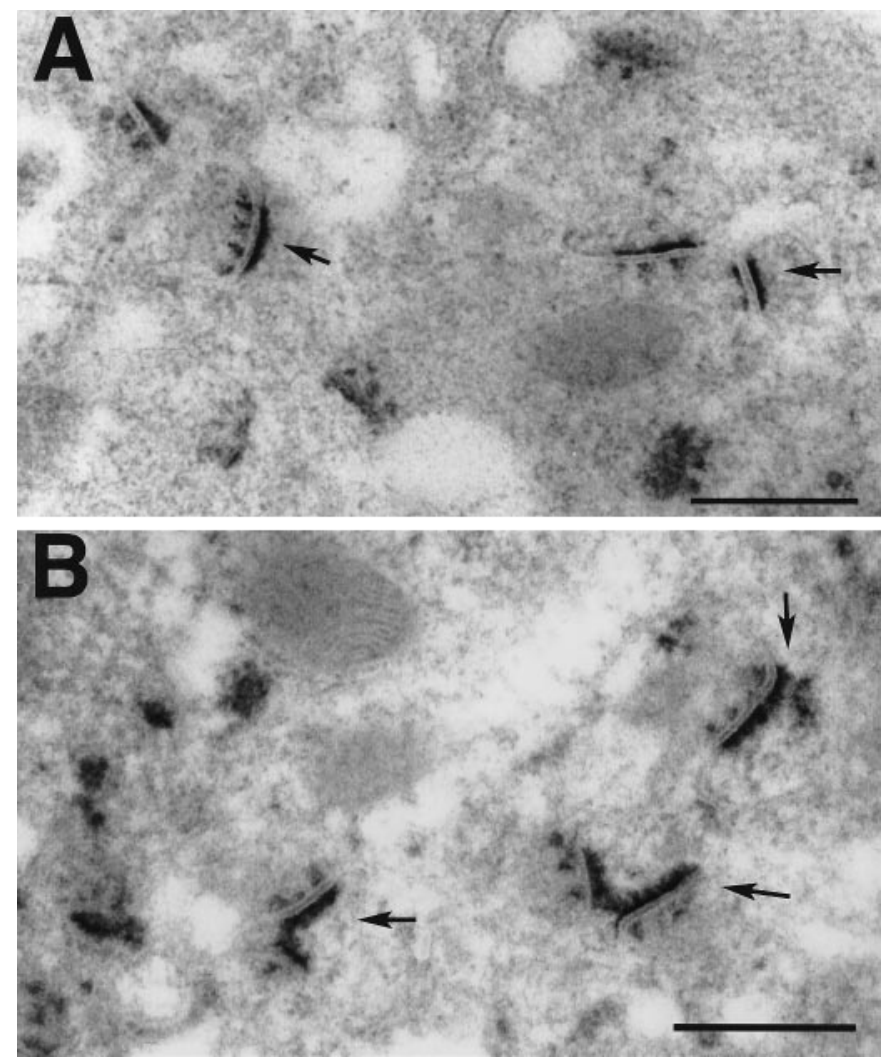

Figure 3. Electron micrographs of E-PTA-stained PSDs (arrows) in neocortical tissue sections of sham-operated control $(A)$ and $4 \mathrm{hr}$ of reperfusion $(B)$. Three tissue sections from three different rats in each group were used for electron microscopic study. Note the increased thickness and fluffier appearance of the PSDs in the postischemic brain, as compared with control. Scale bars in $A$ and $B, 0.5 \mu \mathrm{m}$.

$N$-ethylmaleimide-sensitive fusion protein (NSF) and the $73 \mathrm{kDa}$ is the heat-shock cognate protein-70 (HSC70). Both NSF and HSC70 are protein assembly ATPases that are involved in protein trafficking (Chappell et al., 1986; Söllner et al., 1993; Rothman, 1996). The 51 and the $59-61 \mathrm{kDa}$ are $\alpha$ - and $\beta$-, $\beta^{\prime}$-subunits of CaM-kinase II that translocate to PSDs after ischemia. The 105 $\mathrm{kDa}$ proteins belong to the PSD-95 family and are slightly decreased in reperfused PSDs (Cho et al., 1992). The $55 \mathrm{kDa}$ protein is $\beta$-tubulin that is unchanged after ischemia. We did not succeed in mapping the 63,23, and $18 \mathrm{kDa}$ bands because of limited samples. There were no consistent changes in the protein profile of the light membrane fraction (LMs; Fig. 5A).

To confirm the ischemia-induced PSD proteins identified by protein microsequencing, we studied PSD protein composition by Western blot analysis with specific antibodies. The experiments were conducted in four different PSD preparations from controls or from brains subject to $4 \mathrm{hr}$ of reperfusion. Two representative blots are shown in each figure, and observations were consistent across the four preparations. Five micrograms of PSDs and $40 \mu \mathrm{g}$ of LMs were used in each lane of the immunoblots. Both NMDA receptor subunit-1 (NR1) and -2 (NR2) were highly enriched in PSDs, as compared with the LMs (Fig. 6, NR1 and NR2), which was consistent with previous biochemical and immunoelectron microscopic studies (Moon et al., 1994; Petralia et al., 1994). Levels of these glutamate receptors were unchanged in the PSDs and tended to be decreased in LMs at $4 \mathrm{hr}$ of reperfusion (Fig. 6, $N R 1$ and NR2). In contrast, brain-derived neurotrophic factor

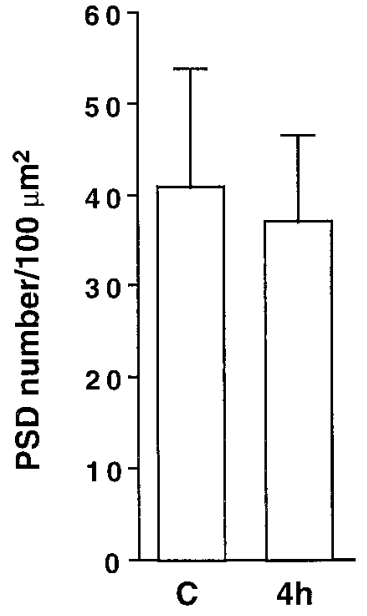

Figure 4. Synaptic density in E-PTA-stained cortical sections. Tissue sections were from sham-operated controls $(C)$ and $4 \mathrm{hr}$ of reperfusion (4h) after 15 min of transient cerebral ischemia. Electron micrographs of E-PTA-stained synapses photographed at a magnification of $8300 \times$ were obtained and scanned into a computer. Data were expressed as mean \pm SD. No significant difference was observed between these two groups (Student's $t$ test).

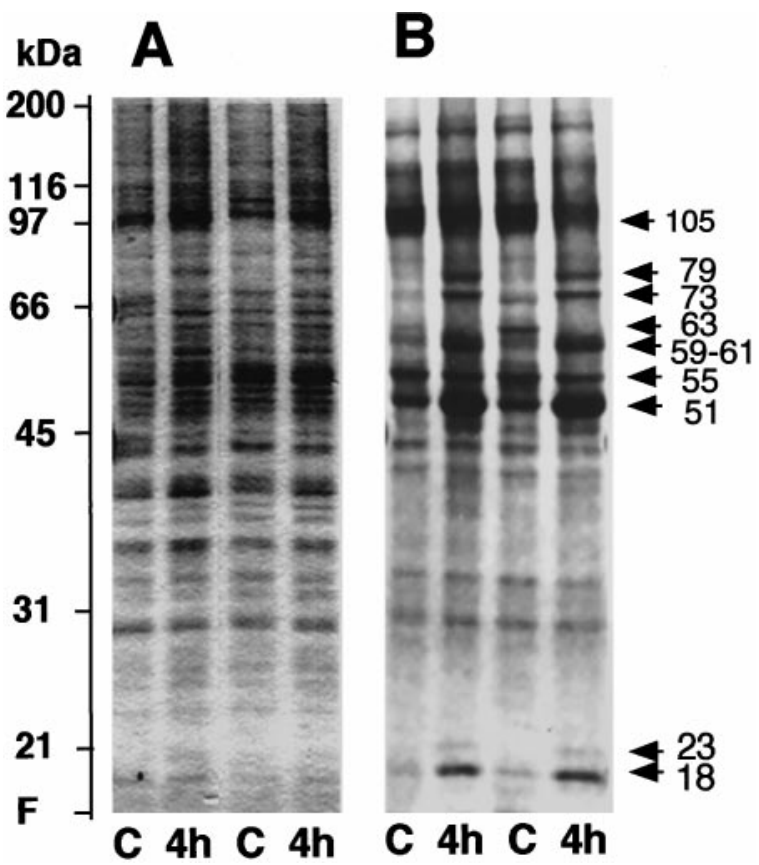

Figure 5. Protein profiles of light membranes $(A)$ and isolated PSDs $(B)$. PSD fractions (20 $\mu \mathrm{g}$ of protein) from control rats $(C)$ and rats subjected to $15 \mathrm{~min}$ of ischemia, followed by $4 \mathrm{hr}$ of reperfusion $(4 h)$, were used in each lane for SDS-PAGE; gels were stained with Coomassie blue. The gels were dried and photographed. Molecular standards are indicated in $\mathrm{kDa}$ on the left. Molecular sizes of the altered proteins are calculated and labeled in $\mathrm{kDa}$ with arrows on the right.

(BDNF) receptor gp145trkB (Fig. 6, trkB) and the two protein assembly ATPases, NSF (Fig. 6, NSF) and HSC70 (Fig. 6, HSC), were highly increased in postischemic PSDs and were not altered significantly in the LM fractions, consistent with the results of the internal peptide microsequencing (Table 2). gp95trkB was not detectable in PSDs, and it was unchanged in LM fractions after ischemia (Fig. 6, trkB).

CaM-kinase was present in control PSDs but significantly ac- 
Table 1. peptide sequences of PSD protein bands obtained from SDSPAGE

\begin{tabular}{llll}
$\begin{array}{l}\text { Molecular size } \\
\text { (in kDa) }\end{array}$ & Sequences & $\begin{array}{l}\text { Matched to } \\
\text { residue number }\end{array}$ \\
\hline 105 & SLENVLEINK & $650-659$ & PSD95 family \\
& IHDL & $404-407$ & \\
79 & NFSGAELEGLV & $435-445$ & NSF \\
& VLDDGXLL & $517-524$ & \\
& YVGE(S)EAN(I)XT & $294-302$ & \\
& XXPXYVAFT- & & \\
73 & DXER & $39-51$ & HSP70 family \\
& X(Q)I(H)DIVLV & $331-339$ & \\
$59-61$ & & & CaM·KII \\
& (N)LINQMLXXN & $247-256$ & $\beta-$ chain \\
& XTDEYQLYEDIG & $10-21$ & \\
55 & V(W)HR & $518-521$ & \\
& (V)S(D)XV(V)E(P)Y & $175-183$ & Tubulin $\beta$-chain \\
& IXVYXNEA & $47-54$ & \\
& IRXXYPD & & CaMKII \\
51 & & & $\alpha-$ chain
\end{tabular}

PSD proteins were separated by $8 \%$ SDS-PAGE and blotted to a PVDF membrane. The membrane-bound proteins were excised and digested in situ. Proteolytic fragments were resolved by C18 reverse-phase HPLC. Molecular sizes were calculated according to protein standards on the SDS-gels. $X$ denotes that no residue could be identified unambiguously. () indicate that assignments were made with $<50 \%$ confidence. PSD95, Postsynaptic density protein-95; NSF, $N$-ethylmaleimidesensitive fusion protein; HSP, heat-shock protein; CaM KII, calcium/calmodulindependent protein kinase II.

cumulated in postischemic PSDs (Fig. 7, CaMKII), as predicted by the peptide mapping (see Table 1 ). Protein kinase C- $\beta$ was translocated to the PSDs in a dephosphorylated form and became partly dephosphorylated in LMs after ischemia, as shown by the double bands in Figure 7, PKC (Borner et al., 1989). PSD-95 and the 5-HT receptor $2 \mathrm{~A}$ were decreased slightly in the postischemic PSDs (Fig. 7, PSD95 and 5HT2AR), which may be attributable to the translocation of proteins such as CaM-kinase II to the postischemic PSDs. This translocation would lead to an increase in PSD size, and thus some PSD proteins may appear relatively decreased as compared with control. A summary of ischemia-induced changes of PSD proteins is provided in Table 2.

\section{Purity of the PSD fraction}

The purity of the PSDs was assessed extensively in the electron microscope, and no other subcellular structures were identified in this fraction (see Fig. 2), consistent with several previous studies (Cohen et al., 1977; Carlin et al., 1980). However, it is possible that the PSD fractions might be contaminated by small amounts of other subcellular components, unrecognizable by morphological analysis. To verify that the presence of ischemia-induced PSD proteins was not attributable to contamination of the PSD fraction by presynaptic membranes, Golgi apparatus, endoplasmic reticulum (ER), nuclei, cytosolic proteins, or mitochondria, we analyzed the PSD fractions for several antigens representative for these subcellular structures. p97 is a NSF-like ATPase that is located in Golgi apparatus and ER (Acharya et al., 1995; Rabouille et al., 1995). Syntaxin and synaptophysin are presynaptic proteins located on synaptic vesicles and the presynaptic membrane (Söllner et al., 1993). The cyclic AMP response element binding protein (CREB) is a nuclear protein. In contrast to



Figure 6. Immunoblots of PSD proteins in the PSD fractions (PSDs, left panel ) and light plasma membrane fractions (LMs, right panel). Samples were from control rats $(C)$ and rats subjected to $15 \mathrm{~min}$ of ischemia, followed by $4 \mathrm{hr}$ of reperfusion (4h). The blots were labeled with antibodies against $N R 1, N R 2, \operatorname{TrkB}, N S F$, and HSC70 (HSC) and visualized with an ECL system. Arrows indicate the bands labeled by the specific antibodies. Molecular standards are indicated in $\mathrm{kDa}$ on the right.

\begin{tabular}{|c|c|c|c|}
\hline Molecular size $(\mathrm{kDa})$ & Method & ID & Changes \\
\hline 145 & $\mathrm{Ab}$ & gp145trkB & $\uparrow$ \\
\hline 105 & Seq. $\mathrm{Ab}$ & PSD95 family & $\downarrow$ \\
\hline 79 & Seq. Ab & NSF & $\uparrow$ \\
\hline 76 & $\mathrm{Ab}$ & PKC & $\uparrow$ \\
\hline 73 & Seq. $A b$ & HSC70 & $\uparrow \quad \uparrow$ \\
\hline 61 & Seq. & $\beta^{\prime}-\mathrm{CaMKII}$ & $\uparrow$ \\
\hline 59 & Seq. & $\beta$-CaMKII & $\uparrow \uparrow$ \\
\hline 55 & Seq. $\mathrm{Ab}$ & $\beta$-tubulin & - \\
\hline 53 & $\mathrm{Ab}$ & 5-HT2AR & $\downarrow$ \\
\hline 51 & Seq. $A b$ & $\alpha$-CaMKII & $\uparrow \uparrow$ \\
\hline
\end{tabular}

Proteins were identified by internal peptide sequencing (Seq) and by immunoblotting with specific antibodies $(\mathrm{Ab})$. ID is an abbreviation of identification. Changes of ischemia-induced PSD proteins are indicated by: $\downarrow$, decrease; $\uparrow$, increase; -, unchanged. PSD95, postsynaptic density protein-95; NSF, N-ethylmaleimidesensitive fusion protein; HSC, heat-shock cognate protein; PKC, protein kinase C; 5 -HT2AR, serotonin receptor subtype 2A; CaMKII, calcium/calmodulindependent protein kinase II.

$\beta$-tubulin, a native protein in both PSDs and LMs that was unchanged after ischemia, p97, syntaxin, and synaptophysin were labeled only in the LM fractions (Fig. 8). The LM fraction contained ER, Golgi, and presynaptic membranes when viewed by electron microscopy (data not shown) (Cohen et al., 1977). CREB immunoreactivity was detected in nuclear fractions, but not in the PSDs (Fig. 8, CREB), and MAP kinases (p42 and p44) were present in the cytosolic fraction (S3) but absent in the PSD fractions (Fig. 8, $M A P K$ ). The PSDs do not appear to be contaminated with mitochondria as evaluated by EM (see Fig. 2) and 


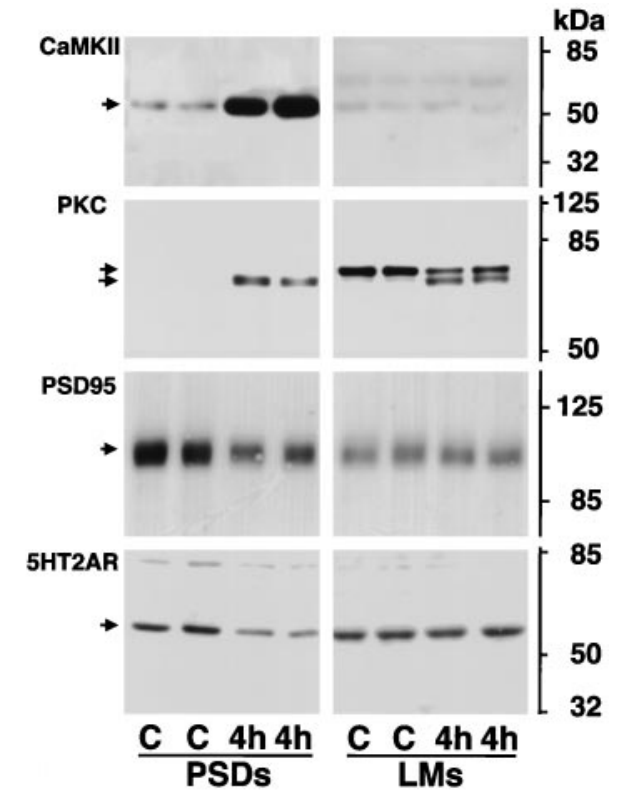

Figure 7. Immunoblots of CaM-kinase II- $\alpha$ (CaMKII), PKC- $\beta$ (PKC), $P S D 95$, and $5 H T 2 A R$ in PSD fractions (PSDs, left panel) and light membrane fractions ( $L M s$, right panel). Samples were from control rats $(C)$ and rats subjected to $15 \mathrm{~min}$ of ischemia, followed by $4 \mathrm{hr}$ of reperfusion (4h). The blots were labeled with the antibodies (arrows) and visualized with an ECL system. Molecular standards are indicated in $\mathrm{kDa}$ on the right.

by cytochrome $c$ oxidase activity that has been shown to be only $0.3 \%$ of that in the mitochondrial fraction (Cohen et al., 1977).

\section{DISCUSSION}

In this study we demonstrated major biochemical and structural modifications of postsynaptic densities at $4 \mathrm{hr}$ of reperfusion after an episode of transient cerebral ischemia. We showed that the fine structure of PSDs was highly modified in both isolated PSDs and brain sections, which was accompanied by changes of PSD protein composition and a 2.5 -fold increase of the PSD yield in postischemic rat cortex relative to shamoperated controls. In agreement with the increase of PSD protein yield and changes of protein composition, NSF, an ATPase required for membrane protein assembly, was highly increased in the PSD fractions after ischemia. Brief ischemia induced the translocation of CaM-kinase II and protein kinase $\mathrm{C}$ to PSDs.

\section{The specificity of PSD modification}

The transient ischemia model used in this study leads to the delayed death of $\sim 10 \%$ of cortical neurons after $\sim 72 \mathrm{hr}$ of reperfusion after the ischemic episode. At the time point examined in this study, $4 \mathrm{hr}$ postischemia, neurons in the cerebral cortex looked normal under the light microscope (data not shown). The lack of obvious pathological changes was confirmed further by electron microscopic analysis of the tissue at $4 \mathrm{hr}$ of reperfusion, which showed no signs of degeneration (data not shown). Other microscopic studies have shown that cortical neurons look normal in $4 \mathrm{hr}$ of reperfusion at the light and EM levels as well, except for increases in membranous organelles and transient disaggregation of polyribosomes (Kirino, 1982; Krino and Sano, 1984a,b; Petito and Pulsinelli, 1984; Smith et al., 1984; Rafols et al., 1995). Thus, the modifications observed in the

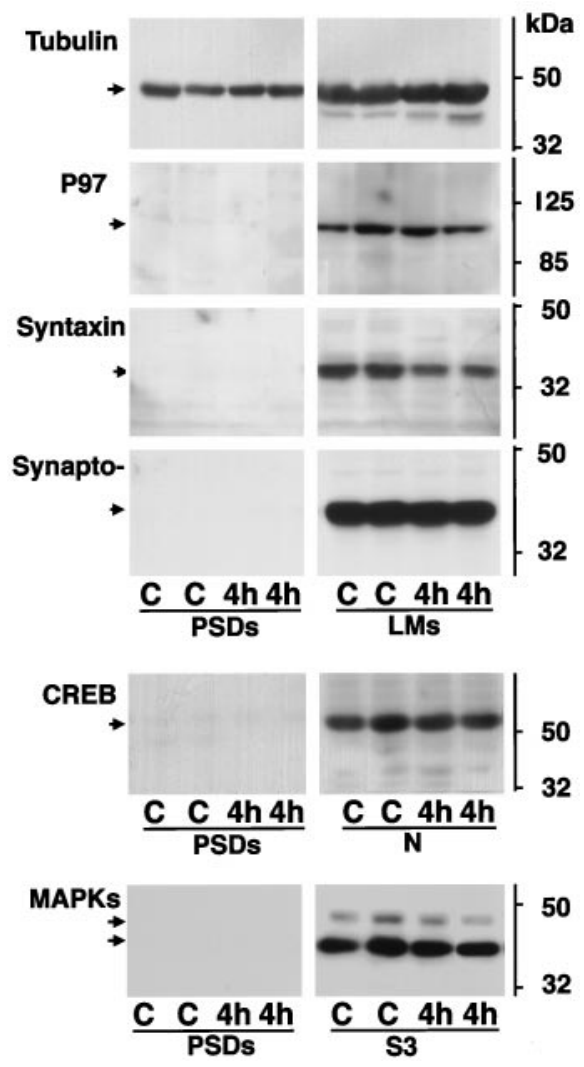

Figure 8. Immunoblots of $\beta$-tubulin (Tubulin), p97 (P97), Syntaxin, synaptophysin (Synapto-), CREB, and MAPKs in the PSD fractions (PSDs, left panel) and light membrane fractions (LMs, right panel), or nuclear fractions $(N$, right panel) or cytosolic fractions $(S 3$, right panel). Samples were from control rats $(C)$ and rats subjected to $15 \mathrm{~min}$ of ischemia, followed by $4 \mathrm{hr}$ of reperfusion $(4 h)$. The blots were labeled with the antibodies (arrows) and visualized with an ECL system. Molecular standards are indicated in $\mathrm{kDa}$ on the right.

present study are well in advance of any obvious neuronal degeneration.

Accumulation of proteins in the postischemic PSDs seems to be a well organized process and is not attributable to a nonspecific aggregation of proteins. In addition to the presynaptic proteins (syntaxin and synaptophysin), Golgi and ER protein (p97), nuclear protein (CREB), and cytosolic proteins (HSP72 and MAP kinases), we have tested a wide variety of proteins such as NCS-1 (the neuronal calcium sensor; Schaad et al., 1996), Arc (activityregulated cytoskeleton-associated protein; Lyford et al., 1995) and the receptor tyrosine kinase EphA4 (Martone et al., 1997) in the PSD fractions. All of these proteins are known to be present in postsynaptic structures, but none is present in the PSD fractions (our unpublished observations). We have shown previously that CaM-kinase II in postischemic neurons is decreased dramatically in the cytoplasm and increased in synaptic structures in vivo by immunocytochemistry as well as by Western blots ( $\mathrm{Hu}$ and Wieloch, 1995; Hu et al., 1995). The present study showed that CaM-kinase II is accumulated specifically to the PSDs in fairly large amounts (see Fig. 5, $51 \mathrm{kDa}$ protein). This suggests that accumulation of proteins in the PSDs occurs in vivo. Furthermore, an NSF-like ATPase, p97, does not accumulate in the PSDs as does NSF. These observations provide further evidence that protein accumulation within the postischemic PSD is not a nonspecific phenomenon. 


\section{Ultrastructural and molecular modification of postischemic PSDs}

A difference in the ultrastructure of PSDs between the control and postischemic sections strongly suggests that modification of PSDs occurs after ischemia. This finding is noteworthy because morphological evidence of synaptic modification has been much sought after to explain excitotoxicity during the postischemic phase. According to both internal peptide microsequencing and Western blot analyses, at least two categories of proteins are markedly increased in PSD fractions after ischemia. One is membrane assembly ATPases like NSF and HSC70, and the other is protein kinases. We were not surprised by the findings that CaM-kinase II and protein kinase $\mathrm{C}$ are translocated to PSDs, because they have been shown to be translocated from cytosol to the particulate fractions in postischemic brain tissues (Cardell et al., 1990; Wieloch et al., 1991; Aronowski et al., 1992). However, the finding was unexpected that two major proteins markedly increased in the postischemic PSDs are the protein assembly ATPases NSF and HSC70. NSF is a central component in the fusion of protein-assembled vesicles and plays a key role in multi-pathways of vesicle-mediated protein transporting between subcellular compartments (Rothman, 1996). These processes include membrane protein assembly, exocytosis, and endocytosis (Söllner et al., 1993; Morgan and Burgoyne, 1995; Rothman, 1996). HSC70 is a constitutively expressed member of the HSP70s and has been identified as an uncoating ATPase that releases clathrin from coated vesicles (Chappell et al., 1986).

Despite extensive recent study of NSF and other presynaptic proteins such as syntaxin, synaptosome-associated protein-25 (SNAP-25), and synaptobrevin, in synaptic vesicle exocytosis during neurotransmitter release in the CNS (Söllner et al., 1993; Rothman, 1996), a role for NSF in the postsynaptic site has not emerged. The marked increase of NSF in the postischemic PSDs suggests that an NSF-related protein assembly machinery may be initiated in PSDs by a brief ischemia episode. Meanwhile, this also raises a question as to which proteins are assembled to PSDs by NSF or HSC70 after ischemic stimulation. We have identified some, but not all, of the proteins that are increased in PSDs after ischemia. The expression of trkB mRNA after ischemia (Merlio et al., 1993) and the marked increase of gp145trkB proteins (BDNF receptor) in postischemic PSDs suggest that some glycosylated membrane proteins are newly synthesized and may be transported to PSDs via a vesicle-mediated mechanism after ischemia. This may be consistent with the observed transformation of the Golgi apparatus into a large cluster of small vesicles in postischemic cortical neurons (Kirino and Sano, 1984b; Petito and Pulsinelli, 1984). It is unlikely that CaM-kinase II and protein kinase $\mathrm{C}$ are transported to PSDs in a similar vesicle-mediated process, because these protein kinases are cytosolic proteins before translocation (Hu et al., 1995).

\section{Dephosphorylation of the protein kinases in the postischemic PSDs}

The accumulation of large amounts of CaM-kinase II as well as lesser amounts of PKC in postischemic PSDs suggests that these kinases may be translocated to the PSDs for modification of receptors or channels immediately after induction of ischemia. It is known that both CaM-kinase II and protein kinase $\mathrm{C}$ are able to modify glutamate receptors (Chen and Huang, 1991; Kitamura et al., 1993; Soderling et al., 1994; Tan et al., 1994). Translocation of protein kinase C is indicative of its activation (Newton, 1997). However, previous studies have indicated that, in ischemia, these translocated kinases may not function properly because both protein kinase $\mathrm{C}$ and $\mathrm{CaM}$-kinase II are inhibited in postischemic tissues (Wieloch et al., 1991; $\mathrm{Hu}$ and Wieloch, 1995; Hu et al., 1995). The reason for this translocation, apparently followed by inactivation, is unknown. Previous studies suggest that the translocation itself does not cause inactivation because both kinases are still active after translocation (Cardell and Wieloch, 1993; Suzuki et al., 1993). It is known that CaM-kinase II is activated by autophosphorylation (Soderling et al., 1994). Activation of protein kinase $\mathrm{C}$ isoforms has been suggested to require a basic phosphorylation by a putative kinase and then autophosphorylation even after its translocation to the membrane (Borner et al., 1989; Newton, 1997). However, because ATP is depleted after a few minutes of ischemia (Siesjö et al., 1988), the protein kinases may not be phosphorylated or autophosphorylated during ischemia. At the same time, phosphatases are still active and able to dephosphorylate most phosphorylated proteins (Hu and Wieloch, 1994). This interpretation is supported by a mobility shift of $\beta$-protein kinase $\mathrm{C}$ to its dephosphorylated position in SDS-PAGE in the postischemic brains (Fig. 7, PKC, double bands). Alternatively, the protein kinase $\mathrm{C}$ recruited to the PSDs might be newly synthesized during the postischemic phase (Newton, 1997).

\section{Significance of PSD modification}

We have shown that an episode of transient ischemia leads to a robust alteration in postsynaptic ultrastructure and molecular composition. This modification of synapses is present well in advance of any obvious neuronal pathology and has been observed to last at least $24 \mathrm{hr}$ after transient ischemia (our unpublished observation). Whether the observed synaptic modification is responsible for long-lasting changes observed in synaptic transmission after ischemia (Andiné et al., 1992; Miyazaki et al., 1993, 1994; Hammond et al., 1994; Gao and Xu, 1996) or contributes to delayed neuronal cell death in some neuronal populations remains to be determined. However, because the majority of asymmetric synapses on dendritic spines in cortex and hippocampus is glutamatergic, one possibility is that the alterations of synaptic structure are indicative of enhanced synaptic input at glutamate synapses. Assembly of proteins such as trkB to PSDs, as shown in this study, may be involved in the facilitation of glutamate transmission (Kang and Schuman, 1995). In the normal brain it has been hypothesized that a large proportion of synapses is not active because the AMPA receptors are not functional (Isaac et al., 1995; Liao et al., 1995). Thus, they are functionally silent even when neurotransmitter release occurs. Stimulation of NMDA receptors leads to the conversion of these silent synapses into functioning glutamatergic synapses. The large and widespread ischemia-induced glutamate release may transform the majority of silent synapses into the active form via the activation of protein assembly mechanisms, thereby amplifying glutamate synaptic input in postischemic neurons. This would lead to excessive usage of synaptic function in postischemic neurons, which, if over a certain threshold, would result in neuronal death. Alternatively, the observed alterations may be a result of synapse degeneration that occurs well ahead of neuronal degeneration in the cell body. This would cause a leakage of extra cellular calcium into postsynaptic neurons and eventually cause cell death.

\section{REFERENCES}

Acharya U, Jacobs R, Peters JM, Watson N, Farquhar MG, Malhotra V

(1995) The formation of Golgi stacks from vesiculated Golgi membranes requires two distinct fusion events. Cell 82:895-904.

Andiné P, Jacobson I, Hagberg H (1992) Enhanced calcium uptake by 
CA1 pyramidal cell dendrites in the post-ischemic phase despite subnormal evoked field potentials: excitatory amino acid receptor dependency and relationship to neuronal damage. J Cereb Blood Flow Metab 12:773-783.

Aronowski J, Grotta JC, Waxham MN (1992) Ischemia-induced translocation of $\mathrm{Ca}^{2+} /$ calmodulin-dependent protein kinase II: potential role in neuronal damage. J Neurochem 58:1743-1753.

Bloom FE, Aghajanian GK (1966) Cytochemistry of synapses: a selective staining method for electron microscopy. Science 154:1575-1577.

Bloom FE, Aghajanian GK (1968) Fine structural and cytochemical analysis of staining of synaptic junctions with phosphotungstic acid. J Ultrastruct Res 22:361-375.

Borner C, Filipuzzi I, Wartmann M, Eppenberger U, Fabbro D (1989) Biosynthesis and posttranslational modifications of protein kinase $\mathrm{C}$ in human breast cancer cells. J Biol Chem 264:13902-13909.

Cardell M, Wieloch T (1993) Time course of the translocation and inhibition of protein kinase $\mathrm{C}$ during complete cerebral ischemia in the rat. J Neurochem 61:1308-1314.

Cardell M, Hu BR, Wieloch T, Zivin J, Saitoh T (1990) Protein kinase $\mathrm{C}$ is translocated to cell membranes during cerebral ischemia. Neurosci Lett 119:228-232.

Carlin RK, Grab DJ, Cohen RS, Siekevitz P (1980) Isolation and characterization of postsynaptic densities from various brain regions: enrichment of different types of postsynaptic densities. J Cell Biol $86: 831-843$.

Chan PH (1996) Role of oxidants in ischemic brain damage. Stroke 27:1124-1129.

Chappell TG, Welch WJ, Schlossman DM, Palter KB, Schlesinger MJ, Rothman JE (1986) Uncoating ATPase is a member of the 70 kilodalton family of stress protein. Cell 45:3-13.

Chen L, Huang LMT (1991) Protein kinase C reduces $\mathrm{Mg}^{2+}$ block of NMDA receptor channels as a mechanism of modulation. Nature 356:521-523.

Cho KO, Hunt CA, Kennedy MB (1992) The rat brain postsynaptic density fraction contains a homolog of the Drosophila discs-large tumor suppressor protein. Neuron 9:929-942.

Choi DW (1995) Calcium: still center-stage in hypoxic-ischemic neuronal death. Trends Neurosci 18:58-60.

Cohen RS, Blomberg F, Berzins K, Siekevitz P (1977) The structure of postsynaptic densities isolated from dog cerebral cortex. J Cell Biol 74:181-203.

Dalkara T, Ayata C, Demirci M, Erdemli G, Onur R (1996) Effects of cerebral ischemia on $N$-methyl-D-aspartate and dihydropyridine sensitive calcium currents: an electrophysiological study in the rat hippocampus in situ. Stroke 27:127-133.

Fischer WH, Karr D, Jackson B, Park M, Vale W (1991) Microsequence analysis of proteins purified by gel electrophoresis. Methods Neurosci 6:69-84.

Furukawa K, Yamana K, Kogure K (1990) Post-ischemic alterations of spontaneous activities in rat hippocampal CA1 neurons. Brain Res 530:257-260.

Gao TM, Xu ZC (1996) In vivo intracellular demonstration of an ischemia-induced postsynaptic potential from CA1 pyramidal neurons in rat hippocampus. Neuroscience 75:665-669.

Hammond C, Crépel V, Ben-Ari Y (1994) Anoxic LTP sheds light on the multiple facets of NMDA receptors. Trends Neurosci 17:497-503.

Harris KM, Kater SB (1994) Dendritic spines: cellular specializations and imparting both stability and flexibility to synaptic function. Annu Rev Neurosci 17:341-371.

Harris KM, Jensen FE, Tsao B (1992) Three-dimensional structure of dendritic spine and synapses in rat hippocampus (CA1) at postnatal day 15 and adult ages: implications for the maturation of synaptic physiology and long-term potentiation. J Neurosci 12:2685-2705.

Hossmann K-A (1993) Disturbances of cerebral protein synthesis and ischemic cell death. Prog Brain Res 96:167-177.

Hu BR, Wieloch T (1993) Stress-induced inhibition of protein synthesis initiation: modulation of initiation factor 2 and guanine nucleotide exchange factor activity following transient cerebral ischemia in the rat. J Neurosci 13:1830-1838.

Hu BR, Wieloch T (1994) Tyrosine phosphorylation and activation of mitogen-activated protein kinase in the rat brain following transient cerebral ischemia. J Neurochem 62:1357-1367.

Hu BR, Wieloch T (1995) Persistent translocation of $\mathrm{Ca}^{2+} /$ calmodulindependent protein kinases II to synaptic junctions in the vulnerable hippocampal CA1 region following transient cerebral ischemia. J Neurochem 64:277-284.

Hu BR, Kamme F, Wieloch T (1995) Alterations of $\mathrm{Ca}^{2+} /$ calmodulindependent protein kinase II and its messenger RNA in the rat hippocampus following normal and hypothermic ischemia. Neuroscience 67:1003-1016.

Isaac JTR, Nicoll R, Malenka RC (1995) Evidence for silent synapses: implication for the expression of LTP. Neuron 15:427-434.

Kang H, Schuman EM (1995) Long-lasting neurotrophin-induced enhancement of synaptic transmission in the adult hippocampus. Science 267:1658-1662.

Kennedy MB (1994) The biochemistry of synaptic regulation in the central nervous system. Annu Rev Biochem 63:571-600.

Kiessling M, Stumm G, Xie Y, Herdegen T, Aguzzi A, Bravo R, Gass P (1993) Differential transcription and translation of immediate early genes in the gerbil hippocampus after transient global ischemia. J Cereb Blood Flow Metab 13:914-924.

Kirino T (1982) Delayed neuronal death in the gerbil hippocampus following ischemia. Brain Res 239:57-69.

Kirino T, Sano K (1984a) Fine structure nature of delayed neuronal death following transient ischemia. Acta Neuropathol (Berl) 62:209-218.

Kirino T, Sano K (1984b) Delayed neuronal death in the rat hippocampus following transient forebrain ischemia. Acta Neuropathol (Berl) 64:139-147.

Kitamura Y, Miyazaki A, Yamanaka Y, Nomura Y (1993) Stimulation effects of protein kinase $\mathrm{C}$ and calcium/calmodulin kinase II on $\mathrm{N}$-methyl-D-aspartate receptor/channels in the postsynaptic density of rat brain. J Neurochem 61:100-109.

Lee KS, Schottler F, Oliver M, Lynch G (1980) Brief bursts of high frequency stimulation produce two types of structural changes in the rat hippocampus. J Neurophysiol 44:247-258.

Liao D, Hessler NA, Malinow R (1995) Activation of postsynaptically silent synapses during pairing-induced LTP in CA1 region of hippocampal slice. Nature 375:400-404.

Lyford GL, Yamagata K, Kaufmann WE, Barnes CA, Sanders LK, Copeland NG, Gilbert DJ, Jenkins NA, Lanahan AA, Worley PF (1995) arc, a growth factor and activity-regulated gene, encodes a novel cytoskeleton-associated protein that is enriched in neuronal dendrites. Cell 14:433-445.

Martone ME, Holash JA, Bayardo A, Pasquale EB, Ellisman MH (1997) Immunolocalization of the receptor tyrosine kinase EphA4 in the adult rat central nervous system. Brain Res, in press.

Merlio JP, Ernfors P, Kodaia Z, Middlemas DS, Bengzon J, Kodaia M, Smith ML, Siesjö BK, Lindvall O, Persson H (1993) Increased production of trkB protein tyrosine kinase receptor after brain insults. Neuron 10:151-164.

Miyazaki S, Katayama Y, Furuichi M, Kinoshita K, Kawamata T, Tsubokawa T (1993) Post-ischemic potentiation of Schaffer collateral CA1 pyramidal cell responses of the rat hippocampus in vivo. Involvement of $N$-methyl-D-aspartate receptors. Brain Res 611:155-159.

Miyazaki S, Katayama Y, Furuichi M, Kano T, Yoshino A, Tsubokawa T (1994) $N$-methyl-D-aspartate receptor-mediated prolonged afterdischarges of CA1 pyramidal cells following transient cerebral ischemia in the rat hippocampus in vivo. Brain Res 657:325-329.

Moon IS, Apperson ML, Kennedy MB (1994) The major tyrosinephosphorylated protein in the postsynaptic density fraction is $N$-methylD-aspartate receptor subunit 2B. Proc Natl Acad Sci USA 91:3954-3958.

Morgan A, Burgoyne RD (1995) Is NSF a fusion protein? Trends Cell Biol 5:335-339.

Neumann-Haefelin T, Wiebner C, Vogel P, Back T, Hossmann K-A (1994) Differential expression of the immediate early genes $c$-fos, $c$-jun, jun $B$, and NGFI-B in the rat brain following transient forebrain ischemia. J Cereb Blood Flow Metab 14:204-216.

Newton AC (1997) Regulation of protein kinase C. Curr Opin Cell Biol 9:161-167.

Nowak Jr TS, Ikeda J, Nakajima T (1990) $70 \mathrm{kDa}$ heat shock protein and c-fos gene expression after transient ischemia. Stroke 21[Suppl 3]:107-111.

Petito CK, Pulsinelli WA (1984) Sequential development of reversible and irreversible neuronal damage following cerebral ischemia. J Neuropathol Exp Neurol 43:141-153.

Petralia RS, Yokotani N, Wenthold RJ (1994) Light and electron microscopy. Curr Opin Neurobiol 4:383-388. 
Pulsinelli WA, Brierley JB, Plum F (1982) Temporal profile of neuronal damage in a model of transient forebrain ischemia. Ann Neurol 11:491-499.

Rabouille C, Levine TP, Peters JM, Warren G (1995) An NSF-like ATPase, p97, and NSF mediate cisternal regrowth from mitotic Golgi fragments. Cell 82:905-914.

Rafols JA, Daya AM, O'Neil BJ, Krause GC, Neumar RW, White BC (1995) Global brain ischemia and reperfusion: Golgi apparatus ultrastructure in neurons selectively vulnerable to death. Acta Neuropathol (Berl) 90:17-30.

Rothman JE (1996) Felix Hoppe-Seyler lecture. Mechanisms of intracellular protein transport. Biol Chem 377:407-410.

Rothman SM, Olney JW (1995) Excitotoxicity and the NMDA receptor-still lethal after eight years. Trends Neurosci 18:57-58.

Schaad NC, De Castro E, Nef S, Hegi S, Hinrichsen R, Martone ME, Ellisman MH, Sikkink R, Rusnak F, Sygush J, Nef P (1996) Direct modulation of calmodulin targets by the neuronal calcium sensor NCS-1. Proc Natl Acad Sci USA 93:9253-9258.

Siesjö BK (1988) Historical overview. Calcium, ischemia, and death of brain cell. Ann NY Acad Sci 522:638-661.

Smith ML, Bendek G, Dahlgren N, Rosen I, Wieloch T, Siesjö BK (1984) Models for studying long-term recovery following forebrain ischemia in the rat. A 2-vessel occlusion model. Acta Neurol Scand 69:385-401.
Soderling TR, Tan SE, McGlade-McCulloh E, Yamamoto H, Fukunaga K (1994) Interactions between glutamate receptors and protein kinases. J Neurobiol 25:304-311.

Söllner T, Bennett MK, Whiteheart SW, Scheller RH, Rothman JE (1993) A protein assembly-disassembly pathway in vitro that may correspond to sequential steps of synaptic vesicle docking, activation, and fusion. Cell 75:409-418.

Suzuki T, Okumura-Noji K, Tanaka R (1993) Rapid translocation of cytosolic $\mathrm{Ca}^{2+} /$ calmodulin-dependent protein kinase II into postsynaptic density after decapitation. J Neurochem 63:1529-1537.

Tan SE, Wenthold RJ, Soderling TR (1994) Phosphorylation of AMPAtype receptors by CaM-kinase II and protein kinase $\mathrm{C}$ in cultured hippocampal neurons. J Neurosci 14:1123-1129.

Thompson RJ (1973) Studies of RNA synthesis in the fractions of nuclei from mammalian cerebral cortex. J Biol Chem 21:19-40.

Wieloch T, Cardell M, Hu BR, Zivin JA, Saitoh T (1991) Changes in the activity of protein kinase $\mathrm{C}$ and the subcellular redistribution of its isoforms during and following forebrain ischemia. $\mathrm{J}$ Neurochem $56: 1227-1235$.

Xu ZC (1995) Neurophysiological changes of spiny neurons in the rat neostriatum after transient forebrain ischemia: an in vivo intracellular recording and staining study. Neuroscience 67:823-836. 